Takashi Yokota • Tomoko Nakata - Shiro Minami

Jyoji Inazawa $\cdot$ Mitsuru Emi

\title{
Genomic organization and chromosomal mapping of ELKS, a gene rearranged in a papillary thyroid carcinoma
}

Received: August 18, 1999 / Accepted: September 22, 1999

\begin{abstract}
We recently isolated a novel cDNA, designated ELKS, that was fused to RET cDNA in a papillary thyroid carcinoma. Its encoded polypeptide sequence was rich in glutamic acid (E), leucine (L), lysine (K), and serine (S), and was characterized by the presence of nine alpha-helical coiled-coil domains consisting of periodic heptad repeats. We have now cloned the entire structure of the human ELKS gene from within a 700-kb genomic region represented by overlapping bacteriophage P1-derived artificial chromosome (PAC) and bacterial artificial chromosome (BAC) clones, and localized it to chromosomal band 12p13.3 by fluorescence in situ hybridization. The gene is approximately $500 \mathrm{~kb}$ long, with 19 exons and 18 introns; the transcription initiation site within exon 1 is separate from the initiation codon (in exon 2). Analysis of the exon/intron structure revealed that introns interrupt the coding sequence in such a way that many functional segments of the protein are encoded by distinct exons. Exon 1 encodes the $5^{\prime}$ non-coding region; exons $2,3,6,7,8,9,11,14$, and 15 encode the nine coiled-coil domains. Exons 17-19 constitute the $3^{\prime}$ non-coding region. Analysis of the region immediately upstream of exon 1 showed that it was extremely rich in G/C nucleotides and contained multiple Sp-1 and AP2 binding sequences. The ELKS-RET gene fusion rearrangement we had observed in a papillary thyroid carcinoma occurred between intron 10 of the ELKS gene and intron 11 of $R E T$.
\end{abstract}

T. Yokota $\cdot$ M. Emi $(\square)$

Department of Molecular Biology, Institute of Gerontology, Nippon Medical School, 1-396 Kosugi-cho, Nakahara-ku, Kawasaki 211-8533, Japan

Tel. +81-44-733-5230; Fax +81-44-733-5192

e-mail: memi@nms.ac.jp.

T. Nakata $\cdot$ S. Minami

Department of Bioregulation, Institute of Gerontology, Nippon

Medical School, Kawasaki, Japan

J. Inazawa

Medical Research Institute, Tokyo Medical and Dental University,

Tokyo, Japan
Key words $E L K S \cdot$ Fusion gene $\cdot$ Break point $\cdot$ Papillary thyroid carcinoma

\section{Introduction}

Proto-oncogenes TRKA and RET, both of which encode receptor-tyrosine kinases, are occasionally rearranged in primary papillary thyroid carcinomas. TRKA is a receptor for nerve growth factor (Klein et al. 1991); RET forms receptor complexes with other molecules that transmit signals of its ligands, which include glial cell line-derived neurotrophic factor (GDNF; Jing et al. 1996), neurturin (NTN; Klein et al. 1998), persephin (PSP; Milbrandt et al. 1998), and artemin (Balon et al. 1998). In affected tumors, these two genes form chimeric oncogenes by fusing their tyrosine kinase domains with $5^{\prime}$ portions of different activating genes (Jhiang and Mazzaferri 1994). Four kinds of chimeric oncogenes involving RET have been reported in papillary thyroid carcinomas: RET/PTC1 (Grieco et al. 1990), RET/ PTC2 (Bongarzone et al. 1993), RET/PTC3 (Bongarzone et al. 1994; Jhiang and Mazzaferri 1994; Santoro et al. 1994), and RET/PTC5 (Klugbauer et al. 1998). Their 5'-end sequences consist of genes encoding, respectively, $\mathrm{H} 4$, regulatory subunit Ri $\alpha$ of protein kinase A, RFG/ELE1, and RFG5.

Recently, we identified a novel cDNA (ELKS), the 5 ' portion of which was fused to the RET gene in a papillary thyroid carcinoma as a consequence of a translocation, $\mathrm{t}(10 ; 12)(\mathrm{q} 11 ; \mathrm{p} 13)$ (Nakata et al. 1999). The ELKS cDNA encodes a novel 948-amino-acid peptide that is expressed ubiquitously in human tissues. The presence of multiple coiled-coil domains in the ELKS product suggests that this protein is likely to form dimers. To investigate the molecular basis of the rearrangement we observed in the thyroid tumor, we determined the genomic structure and chromosomal localization of the human ELKS gene. 


\section{Material and methods}

Cloning of full-length ELKS cDNA by $5^{\prime}$ rapid amplification of cDNA ends (RACE)

5' RACE experiments were performed with a Marathon cDNA amplification kit (Clontech, Palo Alto, CA, USA), using human brain poly(A) RNA as starting material, according to procedures described previously (Nakajima et al. 1999b). The adapter-ligated cDNA was subjected to two rounds of polymerase chain reactions (PCR), using a first gene-specific primer, (5'-CCCTCCCGTACTGTTGGTTCGACGGTG-3') that corresponds to nucleotides $488-515$ of the ELKS cDNA (Nakata et al. 1999) and a nested genespecific primer (5'-GTAGGAAAGGCGAAAGCCTCAGCACTA-3') that corresponds to nucleotides $142-170$ of ELKS cDNA. Sequencing was performed by the BigDye Terminator cycle-sequencing method, using a 377 ABI Prism automated DNA sequencer (ABI), as described previously (Nakajima et al. 1999a)

Isolation of the human ELKS gene

A bacteriophage P1-derived artificial chromosome (PAC) library and bacterial artificial chromosome (BAC) library containing human genomic DNA pooled in a threedimensional structure (Genome Systems, St. Louis, MO, USA, and Roswell Research Center, Buffalo, NY, USA) was used for the isolation of genomic clones, as described previously (Tsukamoto et al. 1998), using oligonucleotides designed from the ELKS cDNA sequence.

Sequence analysis of exon/intron junctions and the 5 '-flanking region

The nucleotide sequences of exons and their boundaries and the 5'-flanking region were determined by directly sequencing the isolated PAC and BAC clones, using oligonucleotide primers with sequence identity to ELKS cDNA (Nakata et al. 1999). The size of each intron was determined by direct sequencing of the overlapping PAC and BAC genomic clones or estimated by PCR amplification, using LA Taq and two oppositely oriented primers located in the respective flanking exons (Takara, Tokyo, Japan) according to procedures described previously (Nakajima et al. 1999b).

Chromosomal mapping of the human ELKS gene by fluorescence in situ hybridization (FISH)

To assign the human ELKS gene location on human chromosomes, a PAC clone carrying the human PAC chromosomal gene was used as a probe. Fluorescence in situ hybridization using PAC DNA was carried out as described previously (Mukae et al. 1998). The slides were examined through a Nikon epifluorescent microscope equipped with a change-compled device (CCD) camera (Photometrics, Tucson, AZ, USA). Images were captured with Quips (Vysis) software and processed with Adobe Photoshop 3.0 software.

\section{Results and discussion}

Genomic characterization of the ELKS gene

A 700-kb genomic region containing the entire human ELKS gene was obtained from seven overlapping clones. Five of these clones $(232 \mathrm{n} 23,136 \mathrm{j} 23,927 \mathrm{j} 12,60 \mathrm{~g} 23$, and $90 \mathrm{j} 10)$ were isolated by screening a human genomic PAC library; the other two (366a16 and 359b12) were from a human genomic BAC library. The ELKS gene spanned more than $500 \mathrm{~kb}$ and consisted of 19 exons interrupted by 18 introns (Fig. 1). Intron-exon boundary sequences and exon sizes are given in Table 1, along with intron sizes that were either determined by direct sequencing of genomic clones or estimated by PCR amplification using primers located in adjacent exons. Sequences at all exon-intron boundaries were compatible with the consensus sequence for splicing junctions, including AG-GT (Mount 1982). Comparison of the genomic and cDNA sequences revealed that exon 1 and the $5^{\prime}$ half of exon 2 encode the $5^{\prime}$ untranslated region (UTR), while the $3^{\prime}$ portions of exon 2 through exon 16 are coding regions. Exon 17 encodes both the carboxyl-terminal coding region and 3' UTR; exons 18 and 19 encode only the $3^{\prime}$ UTR.

Sequencing and characterization of the $5^{\prime}$ portion of ELKS cDNA

The nucleotide sequence of the partial human ELKS cDNA that we described earlier (Nakata et al. 1999) contained the whole open reading frame (ORF) but lacked a complete sequence of its 5' UTR. We therefore carried out 5' RACE experiments and determined the full-length sequence that included an additional $12 \mathrm{bp}$ of cDNA sequence on the $5^{\prime}$ end (Fig. 2). In this manner we determined that the fulllength human ELKS cDNA consists of $406 \mathrm{bp}$ of $5^{\prime}$ UTR, $2,844 \mathrm{bp}$ of coding sequence, and 1,705 bp of $3^{\prime}$ UTR.

The putative promoter sequence of the ELKS gene was examined with the TESS program to identify any binding sites for transcription factors. The G/C-rich 5 '-flanking region was found to contain several $\mathrm{Sp} 1$ sites and AP2 sites. No CAAT or TATA box was present in the 5 -flanking region of the ELKS gene. These features are characteristic of the promoters of housekeeping genes (Dynan 1986).

\section{Chromosomal mapping}

PAC genomic clones served as probes to localize the ELKS gene by fluorescence in situ hybridization on metaphase chromosomes. Clear fluorescent signals were present on chromosomal band 12p13.3 (Fig. 3). We had already linked 


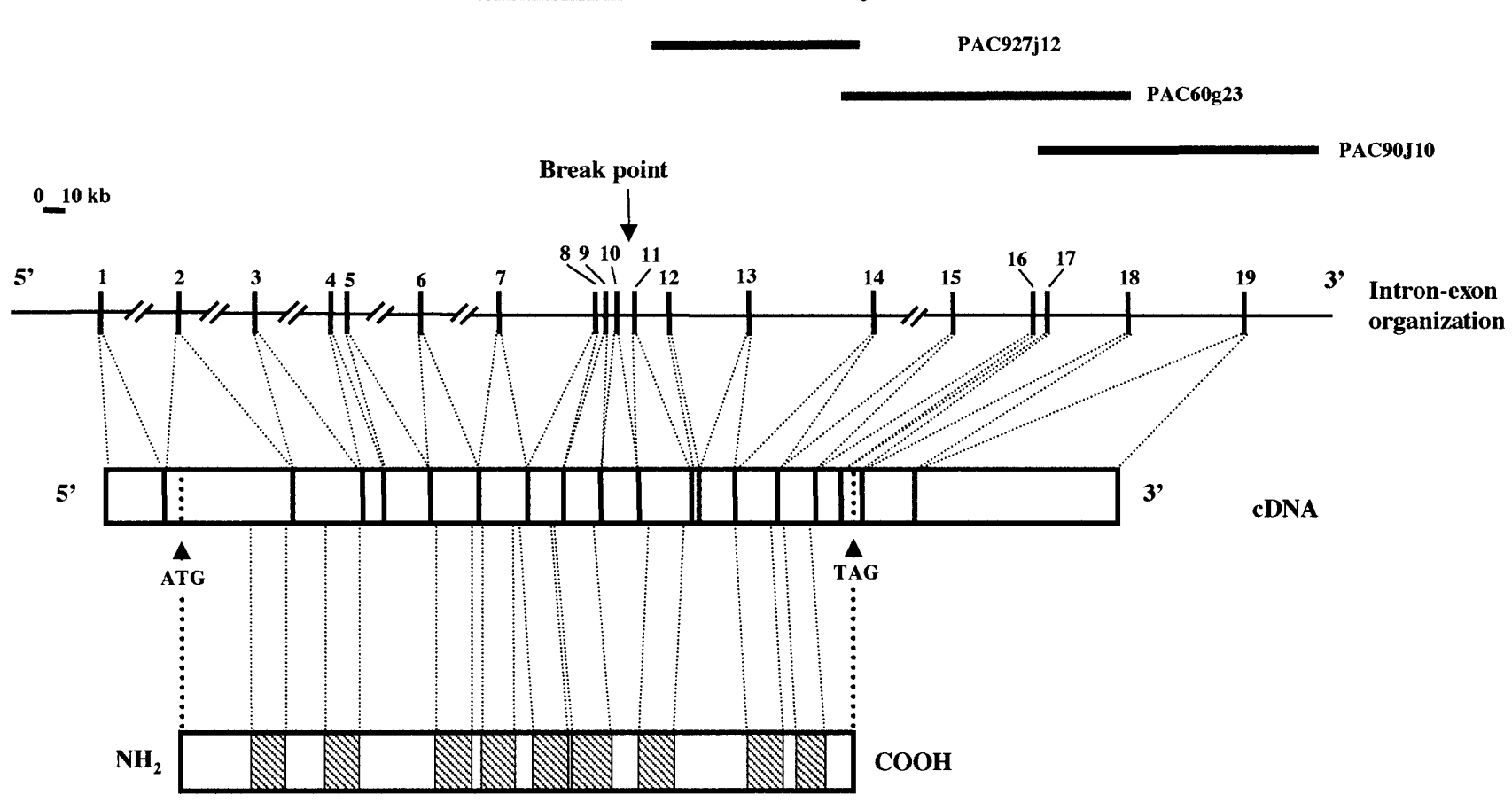

Fig. 1. Upper panel, Genomic structure and map of the human ELKS gene. Overlapping PAC and BAC genomic clones that cover the entire region are shown above the map. Lower panel, Relationship between exonic organization and functional domains of $E L K S$. A translation initiation codon (ATG) is present in exon 2, and a translation stop codon (TGA) in exon 17. Exons are represented by black-outlined boxes, and the breakpoint of the ELKS gene rearrangement observed in a papillary thyroid carcinoma is indicated by the vertical arrow. Coiled-coil domains are indicated by hatched boxes

Table 1. Exon/intron organization of human ELKS gene

\begin{tabular}{|c|c|c|c|c|c|c|}
\hline \multirow{2}{*}{$\begin{array}{l}\text { Exon } \\
\text { Number }\end{array}$} & \multirow{2}{*}{$\begin{array}{l}\text { Exon size } \\
\text { (bp) }\end{array}$} & \multicolumn{4}{|c|}{ Sequence at exon/intron junction ${ }^{a}$} & \multirow{2}{*}{$\begin{array}{l}\text { Intron size } \\
\text { (kbp) }\end{array}$} \\
\hline & & 3' Splice acceptor & $5^{\prime}$ End of exon & $3^{\prime}$ End of exon & 5' Splice donor & \\
\hline 1 & 250 & & & GCGGAGCTGTAG & gtgaggcttcgcgaccccet & ND \\
\hline 2 & 825 & gtgtgatcttttcattacag & ATATGGTGTAAG & GAGGAAAACCAG & gtaagttctacgtgtgttta & ND \\
\hline 3 & 417 & tctttttgtcttggttctga & CACATGCAGATG & ATGTTGAGAGAG & gtatgtgactacttttttag & ND \\
\hline 4 & 75 & tttctgcctcttttctacag & GAGATCGATCGA & ATTGAGATGAAG & gtaagtgagaatctagtaaa & 3.8 \\
\hline 5 & 156 & aaatcttccattgtcttcag & GATTCAAAAATT & ATGAAAAATAAG & gtaatggcatgtgagacttt & ND \\
\hline 6 & 168 & gtgttttacttcttttctag & ATTGGCCAGGTG & CTGCAGACTGAG & gtagaaacaattctgggatt & ND \\
\hline 7 & 169 & taaactcctacattcttag & GTGGATGCTCTC & CTTCAGAAGAAG & gtaaggtacaggtgtttcga & 39 \\
\hline 8 & 137 & aaatatttatgtacatttag & ATTGAAAATCTT & CTTGCAGAGAAA & gtgagtggctggccccaact & 1.3 \\
\hline 9 & 141 & ttgatatattctctcatcag & GAGCGGACAATT & TCAGAGAAAGAG & gttaagctccccaaaatgga & 1.2 \\
\hline 10 & 141 & agatgtgtgttccttctttt & AGGCTTCACTTT & CAATTGAAAAAG & gttaaagaaaaaatttcaca & 6.4 \\
\hline 11 & 194 & tgaaatgcttttctttgtag & GCACATGAGGCA & TGAGTTGGAAAG & gtaagaaagtgaagctgatt & 14.6 \\
\hline 12 & 12 & ggatttcctgtttccttcag & TCТСАССТСАAG & TCТСАССТСАAG & gtcagtatgcttgcactaaa & 32 \\
\hline 13 & 136 & ttttctccttctgtcattag & GCAAGTGAAAGA & CAGCAGCTACAG & gttagaacacaaggagaatc & 53 \\
\hline 14 & 161 & ctttcccatatttatgatag & GTGGAGGAGTTA & TCTGGAGATGAA & gtaagtgtttgtagtcttat & 81.9 \\
\hline 15 & 145 & gcatttgctttcttttgcag & GCAAGAAGCTCT & СTTAAGCAGCAG & gtattattaaatgccagcag & 36 \\
\hline 16 & 99 & tatgaataatttcttcctag & ACGCAAAATCGA & TCCCCAGACCAG & gtaagatggctctggaatgt & 2.2 \\
\hline 17 & 65 & gtcatctctctcccgtgtag & GATGAGGAGGAG & TTGTTCAGAACG & gtgagaaacagctttcctta & 34.3 \\
\hline 18 & 189 & attttatttttttgcettag & ATCATCCAGCCC & ACCCGGGGGCAG & gtgagcctctcactcaaact & 45 \\
\hline 19 & 1475 & agaagatgacccgggggcag & CTTCAGGATGAG & & & \\
\hline
\end{tabular}

The lowercase letters refer to intron sequences and the uppercase letters to exon sequences

${ }^{a}$ The sequences of exon/intron boundaries were determined as described under Materials and Methods

${ }^{\mathrm{b}}$ The intron sizes were estimated by size-fractionating polymerase chain reaction-amplified fragments, using agarose gel electrophoresis, or by direct sequencing of PAC and BAC genomic clones, as described under Material and Methods

ND; Not determined 
Fig. 2. Nucleotide sequence of the $5^{\prime}$-region of human ELKS. The putative transcriptional start site predicted by the $5^{\prime}$ rapid amplification of cDNA ends (RACE) experiment is indicated by an asterisk. The initiation codon (ATG) is indicated by bold type and underlined. Potential SP-1 and AP-2 binding sequences are indicated

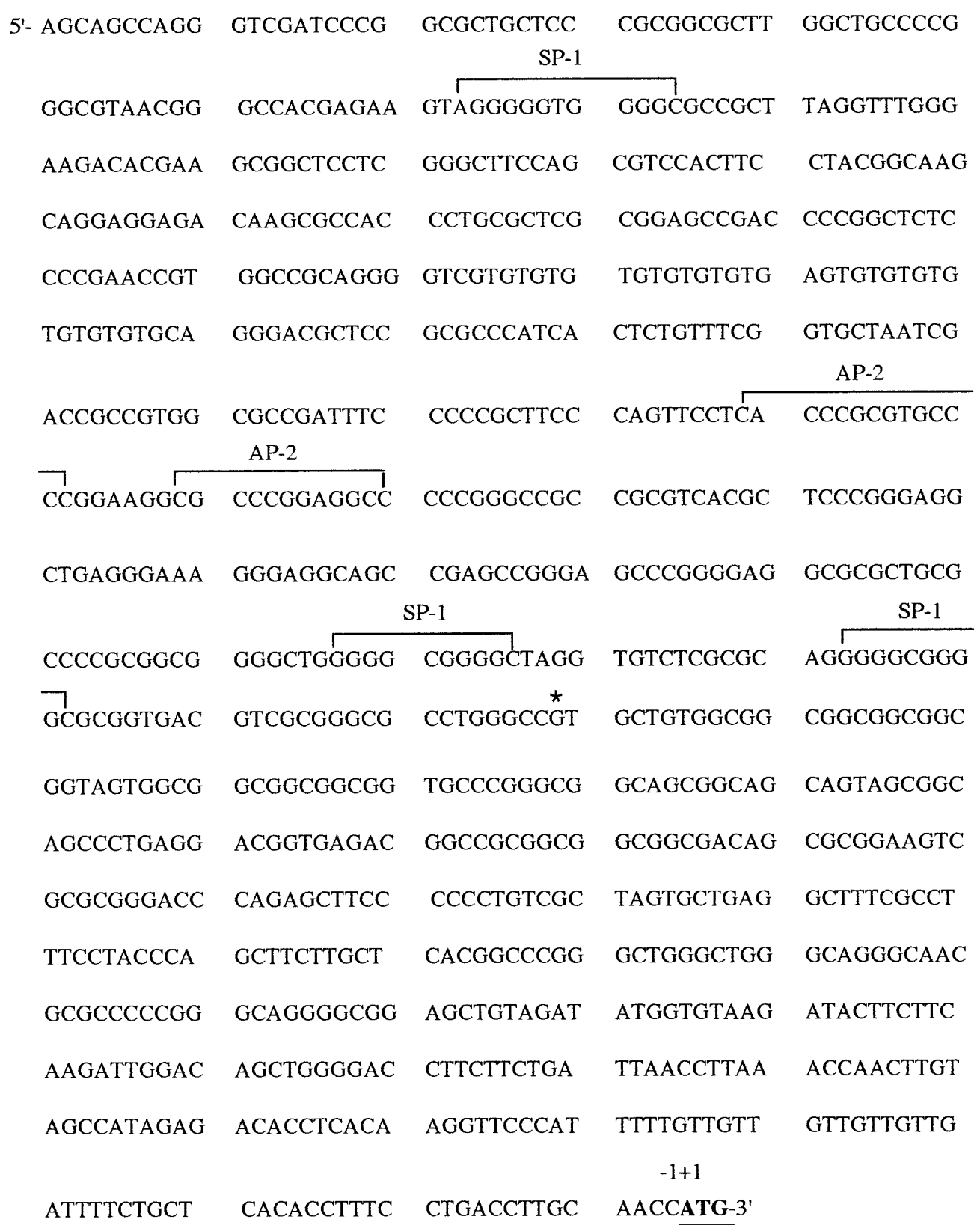

the ELKS sequence to DNA markers on $12 \mathrm{p} 13$ by radiation hybrid mapping, using the Stanford G3 hybrid panels (Nakata et al. 1999).

Exon organization and protein domains

The lower panel of Fig. 1 confirms the relationship between exon organization and protein domains that we had predicted previously (Nakata et al. 1999). The secondary structure of the ELKS sequence is likely to contain alpha-helical coiled-coil domains, because of the presence of heptad repeats in each of the helical-domain regions. The Multi Coil program (version 1-0, window size 2.1) predicted that ELKS protein would contain nine coiled-coil domains. The transcription-initiation site within exon 1 is separate from the initiation codon in exon 2. Exons 2-17 are coding elements; exons 17-19 encode the 3' UTR. Introns interrupt the protein-coding sequence in such a way that many protein segments are encoded by distinct exons; thus, each of seven coiled-coil domains are encoded by exons $2,3,6,7,11,14$, and 15, respectively. The other two coiled-coil domains are encoded by exons 7-8 and exons 8-9. An exon/intron structure of this nature indicates that the gene consists of a mosaic of exons that individually encode functional domains.

Rearrangement of ELKS and RET genes in a papillary thyroid carcinoma

We previously showed that amino acid 691 of $E L K S$ was fused to amino acid 713 of $R E T$ in a papillary thyroid carcinoma; ie, the kinase domain of RET starting from exon 12 
Fig. 3. Chromosomal localization of human ELKS gene to 12p13.3 (arrows) by fluorescence in situ hybridization in metaphase chromosomes

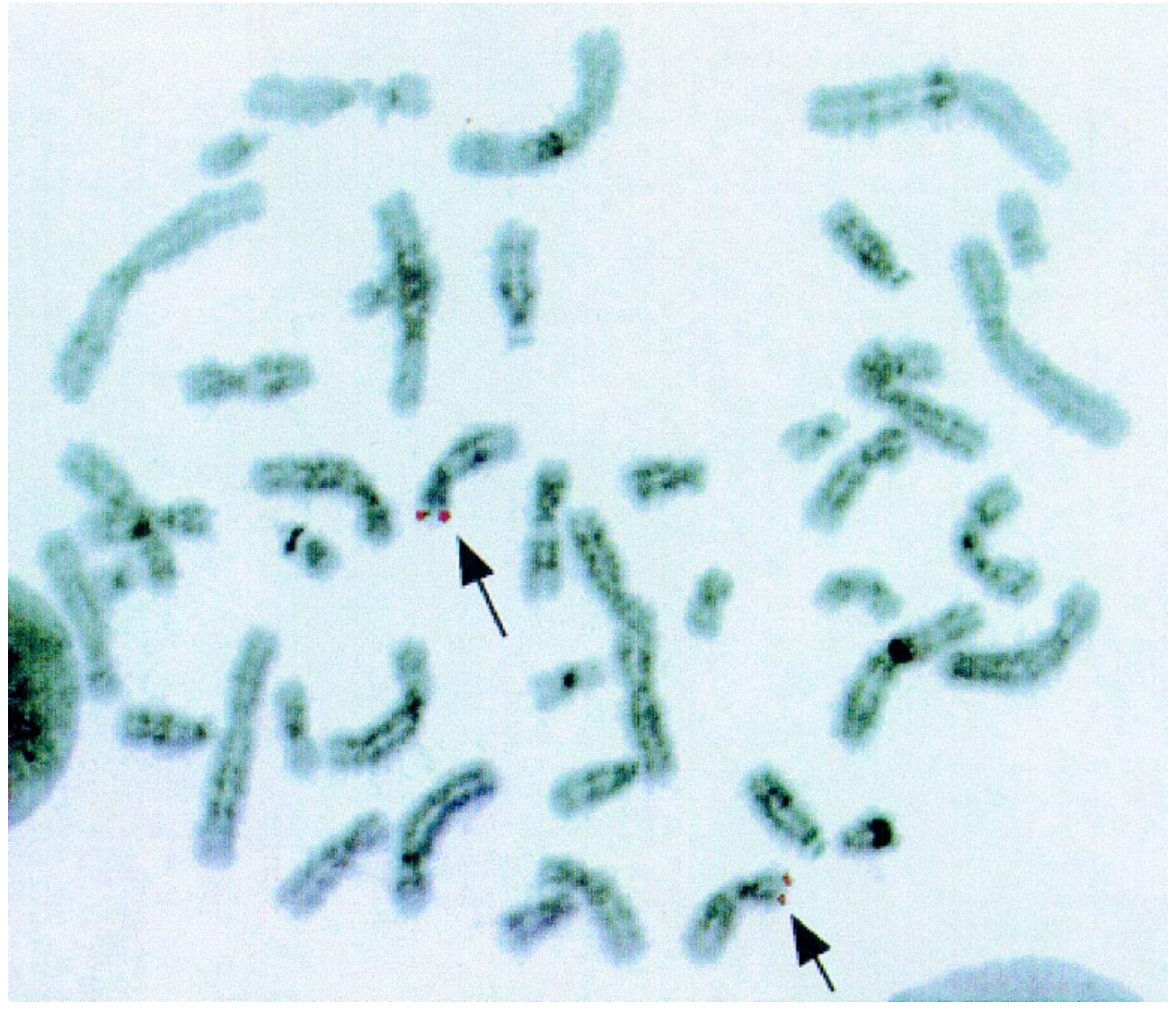

of the RET gene was juxtaposed to a coiled-coil structure of the $5^{\prime}$ portion of the ELKS cDNA sequence (Nakata et al. 1999). The fusion occurred at the end of exon 10 of the $E L K S$ gene, indicating that rearrangement in the tumor genome involved intron 10 of ELKS and intron 11 of RET.

Four other kinds of chimeric oncogenes involving RET have been reported by others in papillary thyroid carcinomas: RET/PTC1 (Grieco et al. 1990), RET/PTC2 (Bongarzone et al. 1993), RET/PTC3 (Bongarzone et al. 1994; Jhiang et al. 1994; Santoro et al. 1994), and RET/ PTC5 (Klugbauer et al. 1998). Their 5'-end sequences consist of genes encoding, respectively, $\mathrm{H} 4$, regulatory subunit Ri $\alpha$ of protein kinase A, RFG/ELE1, and RFG5. The breakpoints of RET/PTC1 and RET/PTC3 occur within intron 1 of the $H 4$ gene and intron 5 of the ELE1 gene, respectively (Smanik et al. 1995). The genomic breakpoints of the RET proto-oncogene in all four previously described forms of RET rearrangement had occurred within intron 11 of the RET structure, a location which separates the transmembrane domain from the tyrosine kinase domain of RET protein. As the ELKS-RET gene fusion also disrupted intron 11 of RET, our results support the idea that all RETrelated fusion genes encode proteins with a RET kinase domain at the carboxyl terminus. We previously synthesized a ${ }^{35} \mathrm{~S}$-Met-labeled ELKS-RET fusion protein in vitro and showed that it actually did form dimers (Nakata et al. 1999). The combined results appear to indicate that constitutive dimerization of rearranged RET, mediated by events within intron 11 that fuse the kinase domain to genes that have coiled-coil structures, may be a general mechanism for activating RET-receptor tyrosine kinases and promoting oncogenesis in papillary thyroid carcinomas.

Acknowledgments This work was supported by Grants-in-Aid from the Ministry of Education, Science, Sports, and Culture of Japan and the Ministry of Health and Welfare of Japan; and by a Novartis Foundation Research Grant.

\section{References}

Balon RH, Tansey MG, Lampe PA, Fahrner TJ, Enomoto H, Simburger KS, Leitner ML, Araki T, Johnson EM, Milbrandt J Jr (1998) Artemin, a novel member of the GDNF ligand family, supports peripheral and central neurons and signals through the GFRalpha3-RET receptor complex. Neuron 21:1291-1302

Bongarzone I, Monzini N, Borrello MG, Carcano C, Ferraresi G, Arighi E, Mondellini P, Della Porta G, Pierotti MA (1993) Molecular characterization of a thyroid tumor-specific transforming sequence formed by the fusion of ret tyrosine kinase and the regulatory subunit RI alpha of cyclic AMP-dependent protein kinase A. Mol Cell Biol 13:358-366

Bongarzone I, Butti MG, Coronelli S, Borrello MG, Santoro M, Mondellini P, Pilotti S, Fusco A, Della Porta G, Pierotti MA (1994). Frequent activation of ret protooncogene by fusion with a new activating gene in papillary thyroid carcinomas. Cancer Res 54:2979-2985

Dynan WS (1986) Promoters for house-keeping genes. Trends Genet 2:196-197

Grieco M, Santoro M, Berlingieri MT, Melillo RM, Donghi R, Bongarzone I, Pierotti MA, Della Porta G, Fusco A, Vecchio G (1990) PTC is a novel rearranged form of the ret proto-oncogene and is frequently detected in vivo in human thyroid papillary carcinomas. Cell 60:557-563 
Jhiang SM, Mazzaferri EL (1994) The ret/PTC oncogene in papillary thyroid carcinoma. J Lab Clin Med 123:331-337

Jing S, Wen D, Yu Y, Holst PL, Luo Y, Fang M, Tamir R, Antonio L, Hu Z, Cupples R, Louis JC, Hu S, Altrock BW, Fox GM (1996) GDNFinduced activation of the ret protein tyrosine kinase is mediated by GDNFR-alpha, a novel receptor for GDNF. Cell 85:1113-1124

Klein R, Jing SQ, Nanduri V, O'Rourke E, Barbacid M (1991) The trk proto-oncogene encodes a receptor for nerve growth factor. Cell 65:189-197

Klein RD, Sherman D, Ho WH, Stone D, Bennett GL, Moffat B, Vandlen R, Simmons L, Gu Q, Hongo JA, Devaux B, Poulsen K, Armanini M, Nozaki C, Asai N, Goddard A, Phillips H, Henderson CE, Klugbauer S, Demidchik EP, Lengfelder E, Rabes HM (1998) Detection of a novel type of ret rearrangement (PTC5) in thyroid carcinomas after Chernobyl and analysis of the invoved ret-fused gene RFG5. Cancer Res 58:198-203

Klugbauer S, Demidchik EP, Lengfelder E, Rabes HM (1998) Detection of a novel type of RET rearrangement (PTC5) in thyroid carcinomas after chernobyl and analysis of the involved RET-fused gene RFG5. 58:198-203

Milbrandt J, Desauvage FJ, Fahrner TJ, Baloh RH, Leitner ML, Tansey MG, Lampe PA, Heuckeroth RO, Kotzbauer PT, Simburger KS, Golden JP, Davies JA, Vejsada R, Kato AC, Hynes M, Sherman D, Nishimura M, Wang LC, Vandlen R, Moffat B, Klein RD, Poulsen K, Gray C, Garces A, Henderson CE, et al. (1998) Persephin, a novel neurotrophic factor related to GDNF and Neurturin. Neuron 20:245-253

Mount SM (1982) A catalogue of splice junction sequences. Nucleic Acids Res 10:459-472

Mukae N, Enari M, Sakahira H, Fukuda Y, Inazawa J, Toh H, Nagata
S (1998) Molecular cloning and characterization of human caspaseactivated DNase. Proc Natl Acad Sci USA 95:9123-9128

Nakajima T, Ota N, Kodama T, Emi M (1999a) Isolation and radiation hybrid mapping of a highly polymorphic CA repeat sequence at the SREBP cleavage-activating protein (SCAP) locus. J Hum Genet 44:350-351

Nakajima T, Hamakubo T, Kodama T, Inazawa J, Emi M (1999b) Genomic structure and chromosomal mapping of the human sterol regulatory element binding protein (SREBP) cleavage-activating protein (SCAP) gene. J Hum Genet 44:402-407

Nakata T, Kitamura Y, Shimizu K, Tanaka S, Fujimori M, Yokoyama S, Ito K, Emi M (1999) Fusion of novel gene, ELKS, to RET due to translocation $\mathrm{t}(10 ; 12)(\mathrm{q} 11 ; \mathrm{p} 13)$ in a papillary thyroid carcinoma. Genes Chromosom Cancer 25:97-103

Pierotti MA, Santoro M, Jenkins R, Sozzi G, Bongarzone I, Grieco M, Monzini N, Miozzo M, Herrmann M, Fusco A, Hay I, Della Porta G, Vecchio G (1992) Characterization of an inversion on the long arm of chromosome 10 juxtaposing D10S170 and ret and creating the oncogenic sequence ret/ptc. Proc Natl Acad Sci USA 89:1616-1620

Santoro M, Dathan NA, Berlingieri MT, Bongarzone I, Paulin C, Grieco M, Pierotti MA, Vecchio G, Fusco A (1994) Molecular characterization of RET/PTC3; a novel rearranged version of the RET proto-oncogene in a human thyroid papillary carcinoma. Oncogene 9:509-516

Smanik P, Furminger T, Mazzaferri E, Jhiang S (1995) Breakpoint characterization of the ret/PTC oncogene in human papillary thyroid carcinoma. Hum Mol Genet 4:2313-2318

Tsukamoto K, Ohta N, Shirai Y, Emi M (1998) A highly polymorphic CA repeat marker at the human interleukin 6 receptor (IL6R) locus. J Hum Genet 43:289-290 